\title{
EVALUATING THE RELATIONSHIP BETWEEN CORPORATE PROFITABILITY AND ESG PERFORMANCE WITH GMM-IV METHOD
}

\author{
Short-term financial effects of ESG factors
}

Máté Fain

\begin{abstract}
This study aims to find the answer to the question how the ESG performance of the companies in the MSCI ACWI Index affects short-term profitability. The dependent variables of the analysis are the return on sales and the ROC/WACC ratio measuring added value. The ESG scores are the S\&P Global SAM ratings. As the goal of the study is to assess the short-term effects, the 2019 profitability-ESG relation is examined along with several control variables. In studies analysing sustainability, measurement, specification errors and endogeneity are frequent which we manage by applying GMM procedure with robust instrumental variables. Based on our calculations, the relationship between financial and ESG performance is mostly neutral in the specific industries, which may help the achievement of the sustainable development goals of the United Nations in the long run.
\end{abstract}

JEL codes: $\mathrm{G}_{32}, \mathrm{G}_{34}, \mathrm{Q}_{51}, \mathrm{Q}_{56}, \mathrm{C}_{36}, \mathrm{C}_{5} 8$

Keywords: ESG, sustainable development goals (SDG), GMM-IV, corporate profitability

\section{INTRODUCTION}

As far as present-day companies are concerned, the ESG approach is becoming more and more important. But what does the ESG abbreviation exactly mean? Letter "E" refers to external effects: it is examined how businesses are trying to respond to environmental challenges. Letter "S" refers to social-reputational questions: it is examined how companies are treating, inter alia, their employees, suppliers, consumers, and local communities. Letter " $G$ " focuses on corporate governance and auditing-controlling policies, managers' salaries, shareholders'

1 Máté Fain PhD student, Department of Finance, Corvinus University of Budapest. E-mail: mate. fain@uni-corvinus.hu. 
rights and issues of business ethics. The corporate governance factor is often referred to the principal-agent problem in the literature.

Based on the survey among company leaders, conducted by KPMG (2020) in September 2020, studying the effects of COVID-19, as well, corporate executives consider the environmental, social and corporate governance aspects of the companies they manage to be an increasingly critical factor. 65 per cent of the leaders surveyed believe that environmental and climate change risks will determine the success of their work in the future. Under the influence of COVID-19, the role of the social component, which has had lesser significance so far, is becoming more critical (63 per cent of the company leaders already consider social challenges to be equal to factors $\mathrm{E}$ and $\mathrm{G})$.

Based on the latest report of GSIA (2018) published at the end of 2018, nearly one-third of all assets under management (AUM), i.e. USD 30,000 billion, was managed by fund managers, taking into account aspects of sustainability. Compared to the USD 13,00o billion in 2012, the above-mentioned amount equals an increase of 60 per cent. (In any case, it is worth mentioning that without a uniform definition of "sustainability", it is difficult to determine accurately the actual magnitude of sustainable investments; for example, according to J.P. Morgan (2019), its estimated value is "only" USD 3,00o billion).

The UN's sustainable development programme lasting until 2030 specifies 17 Sustainable Development Goals (SDGs) and 169 objectives aimed at striking a balance between the economic, social and environmental dimensions of sustainable development (Ielasi-Rossolini, 2019; Martí-Ballester, 2020; United Nations, 2015). We have listed some goals which are relevant to this study: promotion of inclusive and sustainable economic growth, employment and decent work for all (SDG8); ensuring sustainable consumption and production patterns (SDG12); urgent action to combat climate change and its impacts ( $\left.\mathrm{SDG}_{13}\right)$.

Based on the information presented so far, the ESG concept has indisputable significance, and the topic has inarguable importance. Consequently, the research question of our study is the following: How does the ESG performance of enterprises affect their short-term profitability? In our view, if the relation mentioned above is at least neutral, enterprises should focus on sustainability even in the short run, as, in this way, they can do good without any substantial changes to their profitability.

To answer the question raised in the first paragraph, we had to compile a reliable database. Our universe of analysis consists of companies traded in global capital markets; therefore, the benchmark index on which the observations of our statistical analyses rest on is the MSCI ACWI Index. The dependent variables of the regression calculations are the return on sales (ROS) and the ROC/WACC ra- 
tio, which reflects added value more adequately; the ESG ratings, the S\&P Global SAM scores (earlier: RobecoSAM); control variables including profitability in the previous year (ROS, ROC/WACC), company size, capital intensity, indebtedness, the average growth of previous years as well as dummies measuring the company's membership to industries and developed/developing areas. The source of the database presented is Bloomberg, while the period of the analysis is 2019, the last closed year, which is in line with the short-term focus of the analysis.

Our methodology is based on regression calculation, relying on two estimation procedures: 1) the Weighted Least Squares estimation method (WLS) to consider the heteroscedastic nature of the data; as well as 2) the generalised method of moments (GMM-IV) using innovative, robust instrumental variables, based on Racicot (2015). The application of the latter is justified by a fact well-known in the literature (see: Ben Lahouel et al., 2019; Liu et al., 2020; Racicot, 2015) which argues that studies examining sustainability often contain measurement and specification errors or the endogeneity of certain explanatory variables. The novelty of this study lies in the fact that, as far as we know, this version of the GMM-IV procedure has not been used by other academicians to analyse the relationship between financial performance and ESG performance.

The remainder of the study includes the following sections. Following the introduction, we provide a short description of the literary background of the relationship between financial performance and ESG performance. In the third section, we provide a more detailed overview of the analysed database. The fourth section deals with the description of the methodology. The fifth section outlines the results of the empirical analysis. The penultimate part gives a short overview of the research limitations as well as the future research directions. The study ends with a summary.

\section{LITERATURE REVIEW}

In literature, several terms and definitions coexist. Daugaard (2019) gives a detailed explanation on how the concept of sustainable corporate operation has evolved and developed over the past few decades. Initially, the term "ethical" was a common phrase. "Ethical" has been replaced by "socially responsible investment" (SRI). The significance of the term "socially" has become controversial and has often been replaced by "sustainable" or has simply been omitted; therefore, the term "responsible investment" (RI) has remained. Nowadays, the "ESG" concept is regularly used, as well, especially in the investment profession. In our study, we do not wish to distinguish these terms; we use them alternately. 
Sustainable investments and responsible corporate behaviour have extensive literature, which goes back to the early 1970s. According to a pioneering study by Moskowitz (1972), responsible corporate behaviour may lead to outstanding financial performance. As opposed to Moskowitz's findings, Friedman (1970) states that the incorporation of the ESG criteria into everyday corporate operation is very costly, which results in lower profitability. These fundamentally contradictory views have determined research to date. The aforementioned two extremes are complemented by a third view, which emphasises neutral relation.

In the following part of our study, we will provide a short description of the three "schools". The above-mentioned theory accepts Moskowitz's viewpoint, claiming that the satisfaction of primary stakeholders (e.g. customers, employees, local communities, shareholders) is of critical importance regarding excellent financial performance (Clarkson, 1995; Freeman, 2010; Hillman and Keim, 2001; Kerti and Keresztúri, 2017; Mitchell et al., 1997).

The so-called "slack" resource theory also recognises the positive relation between ESG and financial performance. At the same time, it assumes reverse causation, i.e. the ESG performance is determined by financial performance: previous good financial performance results in additional resources (cash surplus), from which a company can behave in a socially responsible way (Günther et al., 2012; Orlitzky et al., 2003; Preston and O'Bannon, 1997; Ullmann, 1985; Waddock and Graves, 1998).

The second hypothesis argues for a negative relation: higher ESG performance decreases financial profitability. We emphasise two theories, namely, trade-off and management opportunism hypotheses. The trade-off hypothesis (see: Aupperle et al., 1985; Dam, 2008; Preston and O'Bannon, 1997; Vance, 1975) resonates with Friedman's criticism. Therefore, the representatives of the theory believe that socially responsible corporate behaviour is fairly expensive. They also list various examples: the transfer of financial and physical resources to socially responsible activities, such as charity work, the development of local communities does not show a return (Preston and O'Bannon, 1997). Furthermore, the internalisation of (environmental) externalities leads to higher operating expenses, which also reduces profitability (Dam, 2008). However, we note that some studies contest the latter reasoning. According to Porter and van der Linde (1995:105), corporate environmental pollution is the direct consequence of the inefficient operation. Their reasoning is based on the following: "Pollution is the emission or discharge of a (harmful) substance or energy form into the environment. Fundamentally, it is a manifestation of economic waste and involves unnecessary, inefficient or incomplete utilisation of resources.".

According to the hypothesis of managerial opportunism, corporate managers often follow their interests (Günther et al., 2012; Makni et al., 2009). In periods when financial performance is stable, managers tend to cut "social" expenditures, thus 
maximising their short-term profit. If financial performance decreases, managers embrace social issues which are easy to communicate, but not necessarily profitable, offsetting poor managerial performance. In the case of the trade-off hypothesis, ESG performance explains financial profitability, while in the case of the management opportunism theory, the direction of the relation is the opposite.

The third hypothesis is the "neutrality" assumption: it contends that there is no significant relationship between ESG performance and financial profitability. The hypothesis is often attributed to McWilliams and Siegel (McWilliams-Siegel, $2000,2001)$. In their study published in 2000 , the authors claim that the involvement of the R\&D factors into the analysis of the relations between ESG and financial performance eliminates, viz., neutralises the positive effect mentioned in several earlier studies. In their article published in 2001, they outline the demand and supply model of ESG (however, instead of the term ESG, "corporate social responsibility" is used). They assume that the ESG performance of a company depends on several factors, inter alia, the size of the company, the level of diversification, the amounts invested in $\mathrm{R} \& \mathrm{D}$, as well as advertising; they conclude again that there is no significant relationship between ESG performance and financial performance. At the same time, they acknowledge that the empirical testing of their hypotheses is challenging, having regard to the frequently occurring problem of data shortage. Their hypothesis is supported by several subsequent empirical studies (Bebchuk et al., 2013; Garcia-Castro et al., 2010; Johnson et al., 2009; Menz, 2010).

In the empirical section of our study, we wish to test the so-called "doing well while doing good" concept, which is frequently referred to in the literature (Hamilton et al., 1993), and corresponds to the first theory described in this section, i.e. the testing of the positive relation between ESG and financial profitability. Formally, our hypotheses are the following:

Hypothesis 1: In the short run, enterprises with higher ESG ratings have higher ROS than enterprises with lower ESG ratings.

In addition to net profitability, ESG's effect on value creation, i.e. economic value added, is also examined.

Hypothesis 2: In the short run, companies with better ESG scores produce higher added value, i.e. their ROC/WACC ratio is higher that of companies with lower ESG ratings.

The acceptance of our hypotheses means that it is worth operating in an ESGconscious manner in the short term. In any case, we believe that even if the relationship is neutral, companies should strive to achieve the best possible ESG performance, as in this way, they can "do good", while not sacrificing their profit. 


\section{DATABASE}

To calculate regressions, we downloaded our database from Bloomberg ${ }^{2}$. The observations are the enterprises included in the MSCI All Country World Index in 2019. The members of the MSCI ACWI Index include 23 developed as well as 26 developing countries and are considered to be mid- or large-cap companies.

The first table summarises the variables involved in the analysis, the method of calculation used as well as the Bloomberg codes required for their reproduction. Most of the features listed are accepted variables in the relevant literature. The dependent variables are the aforementioned return on sales (ROS) and added value (ROC/WACC) indicators. The former is regarded as a standard in accounting and finance, while the latter is a measure used in business valuation. Its numerator is the return on capital, whereas its denominator is the weighted average cost of capital. If the value of the index is over 1.oo, the company concerned is valuecreating in the financial sense (Juhász, 2018).

The key variable of the analysis is the composite ESG score of companies. This index concentrates the otherwise extremely diverse features of businesses in a score ranging from o to $100^{3}$. The higher it is, the better the analysed company performs. Several participants operate in the ESG rating market; Escrig-Olmedo et al. (2019) deal with them in detail. In the analysis, we applied SAM ratings (earlier: RobecoSAM). It is important to mention that these scores are not suitable for comparison spanning industries, "only" for comparison within industries; therefore, our analysis is limited to the assessment of different sectors. The companies of in our analysis were classified according to the SAM industrial classification, and, in the end, the following sectors were analysed: banking sector, chemical industry, food industry, manufacture of machinery, pharmaceutical industry, commerce and transportation. Our sample consists of 624 enterprises in total. We analysed only those industries which had more than 60 participants in 2019, as this condition fulfils the criterion of 5-10 observations per explanatory variable (Kovács, 2014).

2 On Bloomberg's role in higher education and research, see: NAFFA (2018).

3 Workplace health programmes offered by companies can be good examples for several ESG features (SzAвó-JuHÁsz, 2019a, 2019b) 
Table 1

Variables applied in the analysis

\begin{tabular}{|c|c|c|c|c|}
\hline $\begin{array}{l}\text { Name } \\
\text { of the factor }\end{array}$ & $\begin{array}{c}\text { Name } \\
\text { of the variable }\end{array}$ & Abbreviation & $\begin{array}{c}\text { Calculation, methodological } \\
\text { background }\end{array}$ & Bloomberg code \\
\hline \multirow{2}{*}{ Profitability } & Return on sales & ROS & $\begin{array}{c}\text { Earnings after taxes (2019) / } \\
\text { Revenue (2019) }\end{array}$ & PROF_MARGIN \\
\hline & Added value index & $\mathrm{ROC} / \mathrm{WACC}$ & $\begin{array}{l}\text { Return on capital (2019) / Weighted } \\
\text { average cost of capital (2019) }\end{array}$ & ROC_WACC_RATIO \\
\hline \multirow{2}{*}{$\begin{array}{l}\text { Profitability } \\
\quad(\mathrm{t}-1)\end{array}$} & Return on sales (2018) & ROS_18 & $\begin{array}{c}\text { Earnings after taxes (2018) / } \\
\text { Revenue (2018) }\end{array}$ & PROF_MARGIN \\
\hline & $\begin{array}{l}\text { Added value index } \\
\text { (2018) }\end{array}$ & $\begin{array}{c}\text { ROC/ } \\
\text { WACC_18 }\end{array}$ & $\begin{array}{l}\text { Return on capital (2018) / Weighted } \\
\text { average cost of capital (2018) }\end{array}$ & ROC_WACC_RATIO \\
\hline \multirow{3}{*}{$\begin{array}{l}\text { Company } \\
\text { size } \\
\text { (SIZE) }\end{array}$} & $\begin{array}{l}\text { Markets capitalisation } \\
\text { (2019) }\end{array}$ & CAP & $\begin{array}{l}\text { ln (Number of shares outstanding } \\
(2019) * \text { Share price }(2019))\end{array}$ & CUR_MKT_CAP \\
\hline & Assets (2019) & ASS & $\begin{array}{l}\ln (\text { all current } \\
\text { and non-current assets (2019)) }\end{array}$ & BS_TOT_ASSET \\
\hline & Net revenue (2019) & REV & $\ln ($ Net sales revenue (2019)) & SALES_REV_TURN \\
\hline \multirow{3}{*}{$\begin{array}{l}\text { Leverage } \\
\text { (LEV) }\end{array}$} & Book leverage & BLEV & $\begin{array}{c}\text { LT debt }+\max (\text { ST debt. }- \text { Cash; } 0) / \\
\text { Equity }+ \text { LT debt. }+ \text { max } \\
\text { (ST debt. }- \text { Cash; 0) / } \\
\text { (all data from 2019) }\end{array}$ & \multirow{3}{*}{$\begin{array}{c}\text { BS_LT_BORROW } \\
\text { BS_TOT_ASSETS } \\
\text { CASS_AND_MER- } \\
\text { KETABLE } \\
\text { EQY_SH_OUT } \\
\text { PX_LAST } \\
\text { TOT_COMMON_ } \\
\text { EQY }\end{array}$} \\
\hline & $\begin{array}{l}\text { Indebtedness based } \\
\text { on market capitalisa- } \\
\text { tion }\end{array}$ & MLEV & $\begin{array}{c}\text { LT debt. + max (ST debt. }- \text { Cash; 0) / } \\
\text { Market capitalisation + LT debt. + } \\
\text { max (ST debt. - Cash; 0) / } \\
\text { (all data from 2019) }\end{array}$ & \\
\hline & Net debt/Assets & DA & $\begin{array}{c}\text { LT debt. + max (ST debt. - Cash; 0) / } \\
\text { Assets (all data from 2019) }\end{array}$ & \\
\hline $\begin{array}{l}\text { Capital } \\
\text { intensity } \\
(\mathrm{CAP})\end{array}$ & Capital intensity & CAPINT & Assets (2019) / Net revenue (2019) & $\begin{array}{l}\text { BS_TOT_ASSET } \\
\text { SALES_REV_TURN }\end{array}$ \\
\hline \multirow{3}{*}{$\begin{array}{l}\text { Growth } \\
\text { (GRO) }\end{array}$} & $\begin{array}{l}\text { Average annual } \\
\text { growth rate of assets }\end{array}$ & gASSETS & $\begin{array}{l}\text { Average } \Delta \text { assets (2017-2019) / } \\
\text { Average assets (2017-2019) }\end{array}$ & \multirow{3}{*}{$\begin{array}{l}\text { BS_TOT_ASSET } \\
\text { SALES_REV_TURN } \\
\text { IS_INC_BEF_XO_ } \\
\text { ITEM }\end{array}$} \\
\hline & $\begin{array}{l}\text { Average annual } \\
\text { growth rate } \\
\text { of net sales }\end{array}$ & gREV & $\begin{array}{c}\text { Average } \Delta \text { net sales (2017-2019) / } \\
\text { Average sales (2017-2019) / }\end{array}$ & \\
\hline & $\begin{array}{l}\text { Average annual } \\
\text { growth rate of profit } \\
\text { after tax }\end{array}$ & gPAT & $\begin{array}{l}\text { Average } \Delta \text { profit after tax } \\
(2017-2019) / \\
\text { Average profit after tax } \\
(2017-2019) /\end{array}$ & \\
\hline $\begin{array}{l}\text { ESG score } \\
\quad \text { (ESG) }\end{array}$ & $\begin{array}{l}\text { Composite } \\
\text { ESG score }\end{array}$ & ESG & $\begin{array}{l}\text { S\&P Global SAM ratings (earlier: } \\
\text { RobecoSAM) }\end{array}$ & $\begin{array}{l}\text { ROBECOSAM } \\
\text { STBLY_RANK }\end{array}$ \\
\hline \multirow{2}{*}{$\begin{array}{l}\text { Development } \\
\text { (DEV) }\end{array}$} & Developed & DEV & \multirow{2}{*}{$\begin{array}{c}\text { Countries regarded as developed or } \\
\text { developing markets based on the } \\
\text { MSCI }{ }^{\circledR} \text { classification. }\end{array}$} & \\
\hline & Developing & DEVELOPING & & \\
\hline
\end{tabular}

Source: Own editing 
Our control variables include previous year's (2018) profitability (ROS_18 and ROC/WACC_18), which is of critical importance based on literature (and everyday rationality). Garcia-Castro et al. (2010) argues that past financial performance largely affects the decisions of company managers in the current year. Wintoki et al. (2012) and Ben Lahouel et al. (2019) point out that in order to understand the current financial performance, it is necessary to take into account the lagged values of the dependent variable, as the effects of the past shocks on the actual profit cannot be excluded from the assessment. Another important development was that the static models without a lagged dependent variable distorted and typically exaggerated, or overestimated the significance of the independent explanatory variables, such as that of the ESG factors (see: Ben Lahouel et al., 2019).

Among the control variables, all of which are widely used in the literature, we intend to capture firm size (SIZE), leverage (LEV) and growth (GRO) with three company characteristics each. For data saving reasons (it is essential to meet the requirement regarding the proportion of observation number/explanatory variables), the information content of the characteristics was merged in single factors applying principal component analysis (PCA). Among others, company size was used by Brammer-Pavelin (2006, 2008), Cormier-Magnan (2003), Patten (1991); indebtedness by Brammer-Pavelin (2006, 2008), Cormier et al. (2011), Qiu et al. (2016); capital intensity by Russo-Fouts (1997), Wagner (2005) and growth by $\mathrm{Ca}$ pon et al. (1990), Russo-Fouts (1997).

Our initial database included 2,850 corporates. Several enterprises did not have ESG scores or were not traded in 2018; therefore both the return on sales and the added value ratios from 2018 were missing (in the case of only about a dozen companies, other features were missing, as well). Therefore, we filtered out the companies which had even only one missing data from the database (listwise deletion). After the first screening, 2,242 enterprises remained in the database.

Due to the significant distorting effect of extreme observations on regression calculations, we s winsorised each variable, following the works of $L i$ et al. (2020) and Oikonomou et al. (2012), i.e. values lower than 1st percentile and higher than 99th percentile were replaced by these value limits. 


\section{METHODOLOGY}

In the course of the empirical analysis, a linear regression model was estimated based on the following general equations.

$R_{O S}=\beta_{0}+\beta_{1} R O S_{i t-1}+\beta_{2} S I Z E_{i t}+\beta_{3} L E V_{i t}+\beta_{4} C A P_{i t}+\beta_{5} G R O_{i t}+\beta_{6} E S G_{i t}+$ $\beta_{7}$ DEVELOPING $i t+u_{i t}$

In equation (1), the dependent variable $\left(R O S_{i t}\right)$ is the return on sales of the given $i$ enterprise in 2019, while the $E S G_{i t}$ variable refers to the ESG rating of enterprise $i$ on a scale from o to 100. A $R O S_{i t-1}$ is the return on sales of the previous year (2018), which turns the otherwise static model dynamic. Further variables include the control variables described in the previous section.

Similarly to equation (1), a regression can be written on the indicator of the added value, as well.

$R O C / W A C C_{i t}=\beta_{0}+\beta_{1} R O C / W A C C_{i t-1}+\beta_{2} S_{Z I Z E_{i t}}+\beta_{3} L E V_{i t}+\beta_{4} C A P_{i t}+\beta_{5} G R O_{i t}+$ $\beta_{6} E_{S G}+\beta_{7}$ DEVELOPING $i t+u_{i t}$

The variables of the equation can be interpreted similarly to (1); therefore, the variables on the right include the ROC/WACC ratio of the previous period, which dynamises the model.

In fact, the critical methodological question can be raised in the following way: how can the beta parameters of the individual equations be estimated? We followed two procedures: 1) the traditional OLS with robust standard errors controlling for heteroscedasticity (WLS) and 2) the generalised method of moments estimator (GMM-IV) using innovative, robust instrumental variables. The latter can be found in the works of Racicot (2015), Racicot et al. (2019), Racicot Théoret (2014), Roy - Shijin (2018). The GMM-IV method is suitable for handling the different forms of endogeneity hidden in the relationship between financial and ESG performance, which were summarised by Ben Lahouel et al. (2019) in the following three points: 1) simultaneity (reverse causation); 2) distortion caused by an omitted variable and 3) measurement errors. The GMM-IV method explained below can be the solution to the challenges listed above.

In the GMM framework, the estimation function written for beta coefficients applying robust instrumental variables is the following (the deduction below can be found, inter alia, in studies by Racicot and Rentz (2015), Roy and Shijin (2018):

$\hat{\beta} \equiv \operatorname{argmin}_{\beta}\left\{n^{-1}\left[d^{\prime}(y-X \hat{\beta})\right]^{\prime} W n^{-1}\left[d^{\prime}(y-X \hat{\beta})\right]\right\}$

Each variable in (3) will be individually defined. The number of observations is $n$. The second one is $W$, which is a positive definite matrix with the same number 
of rows and columns as matrix $d$ (this is the matrix of the IVs, as distance estimators, which are to be introduced later). Matrix $W$ is a weight matrix, dealing with distortions caused by heteroscedasticity. Dependent variable $y$ is defined as follows:

$y=X \beta+\varepsilon$

In (3), $Y-X \hat{\beta}$ could be replaced by the following formula (residuals):

$\varepsilon=y-X \hat{\beta}$

In formula (4), $X$ is supposed to be the matrix of explanatory variables which cannot be directly observed in reality. The observed matrices of explanatory variables are supposed to be corporate

characteristics measured with (normally distributed $\left.{ }^{4}\right)$ errors $\left(X^{\star}\right)$, i.e. $(v$ is the residual):

$X^{*}=X+v$

Applying matrix $W$, the betas derive from the 2 SLS regression:

$\hat{\beta}=\hat{\beta}_{2 S L S}=\left(X^{\prime} P_{Z} X\right)^{-1} X^{\prime} P_{Z} Y$

Based on formula (7), matrix $P_{z}$, a projection matrix, can be explained:

$P_{Z}=Z\left(Z^{\prime} Z\right)^{-1} Z^{\prime}$

In formula (8), matrix $Z$ is the matrix of IVs, which derives from the optimal combination of the Durbin (1954) and Pal (1980) estimators, applying the GLS method. Using the $P_{z}$ projection matrix (thus the $\mathrm{Z}$ instruments), the value of the explanatory variables is estimated:

$P_{Z} X=Z\left(Z^{\prime} Z\right)^{-1} Z^{\prime} X=\hat{Z \theta}=\hat{X}$

Employing formula (9), the matrix of residuals can be calculated. The calculation is summarised in the formula below:

$d=X-\hat{X}=X-P_{Z} X=\left(I-P_{Z}\right) X$

4 Based on RACICOT and RENTZ (2015), in our study, the mathematical consistency of estimators is proven by the modelling assumption of the normally distributed residuals. This assumption does not restrict the modelling process applied in the analysis. The GMM-IV estimator we propose is based on higher moments of the observed financial data, therefore it is able to express the nonlinear character of the data, which is also one of the major goals of the method. 
In equation (10), $d$ is the matrix of IVs. The individual elements of matrix $d$ can be calculated using (11):

$d_{i t}=x_{i t}-\hat{x}_{i t}$

In fact, an individual $d_{i t}$ can be interpreted as the "filtered" values of endogenous explanatory variables. The method described above eliminates the potential hidden non-linear "behaviour" of explanatory variables. Following this procedure, the following question remains: how to calculate the estimated values of the explanatory variables $\left(x_{i t}\right)$ ? This calculation requires the addition of OLS regressions, in the case of which, the dependent variables are the explanatory variables and the $z$ instruments are the independent variables:

$x_{i t}=\hat{\gamma}_{0}+\hat{z \varphi}+\varsigma_{t}=\hat{x}_{i t}+\varsigma_{t}$

The $z$ instruments, i.e. the $Z=\left\{z_{1}, z_{2}\right\}$ matrix, can be defined by the following formulae:

$z_{1}=x \odot x$

$z_{2}=x \odot x \odot x-3 x\left[\left(D\left(x^{\prime} x / T\right)\right]\right.$

$\operatorname{Diag}\left(x^{\prime} x / T\right)=p \lim _{T \rightarrow \infty}\left(x^{\prime} x / T\right) \odot I_{k}$

Matrix $x$ is the modified matrix of explanatory variables, in which the explanatory variables are corrected by their average (i.e. the average is deducted from each value; thus, we get centred values). $\odot$ is the symbol of the Hadamard product. $\operatorname{Diag}\left(x^{\prime} x / T\right)$ is a diagonal matrix; while $I_{k}$ is an identity matrix of $k \times k$ dimension, where $k$ is the number of explanatory variables ( $T$ is the number of the examined periods).

The $z_{1}$ matrix contains instruments used by Durbin (1954), while the $z_{2}$ matrix contains instruments applied by Pal (1980). These IVs are consistent with those used by Dagenais and Dagenais (1997); therefore, they are suitable for handling the different forms of endogeneity.

\section{RESULTS}

In this chapter, the results of our empirical calculation are presented. First, our results related to hypothesis 1 detailed in the literature review (and the relevant regression (1)) are described, then the results related to hypothesis 2 (equation (2)). Table 2 summarises the findings of the analysis of the relation between the return on sales (ROS) and the ESG performance of the different industries. Panel "A" of 
the table includes regression calculations conducted using the OLS method, while panel "B" those conducted using the GMM-IV method.

Table 2

Relationship between return on sales and ESG performance

\begin{tabular}{|c|c|c|c|c|c|c|c|c|c|c|c|}
\hline \multicolumn{12}{|c|}{ A: OLS method } \\
\hline Industry & FV_18 & SIZE & LEV & CAP & GRO & DEV & ESG & c & adj_R $R^{2}$ & $\mathbf{F}$ & $\mathbf{N}$ \\
\hline $\begin{array}{l}\text { BA } \\
\text { t-stat }\end{array}$ & $\begin{array}{c}0.8302 \\
17.18^{* * *}\end{array}$ & $\begin{array}{c}-0.0069 \\
-1.86^{*}\end{array}$ & $\begin{array}{c}-0.0249 \\
-0.88\end{array}$ & $\begin{array}{c}0.0000 \\
0.13\end{array}$ & $\begin{array}{c}0.1493 \\
1.61\end{array}$ & $\begin{array}{l}-0.0351 \\
-2.65^{\star * *}\end{array}$ & $\begin{array}{c}0.0003 \\
1.71^{*}\end{array}$ & $\begin{array}{l}0.1383 \\
2.7^{* * *}\end{array}$ & 0.73 & $54.86^{* * *}$ & 188 \\
\hline $\begin{array}{l}\mathrm{CH} \\
\text { t-stat }\end{array}$ & $\begin{array}{l}0.7339 \\
5.85^{* * *}\end{array}$ & $\begin{array}{c}0.0126 \\
1.42\end{array}$ & $\begin{array}{c}-0.0458 \\
-0.92\end{array}$ & $\begin{array}{c}-0.0034 \\
-1.16\end{array}$ & $\begin{array}{c}0.0211 \\
0.2\end{array}$ & $\begin{array}{c}0.0251 \\
1.57\end{array}$ & $\begin{array}{c}-0.0003 \\
-1.14\end{array}$ & $\begin{array}{c}-0.0684 \\
-0.91\end{array}$ & 0.29 & $7.09^{* * *}$ & 77 \\
\hline $\begin{array}{l}\text { F } \\
\text { t-stat }\end{array}$ & $\begin{array}{l}0.6013 \\
3.28^{* * *}\end{array}$ & $\begin{array}{c}0.0102 \\
1.22\end{array}$ & $\begin{array}{l}-0.1086 \\
-2.05^{\star *}\end{array}$ & $\begin{array}{c}0.0080 \\
1.94^{*}\end{array}$ & $\begin{array}{c}0.0574 \\
0.36\end{array}$ & $\begin{array}{c}-0.0224 \\
-1.7^{*}\end{array}$ & $\begin{array}{c}0.0002 \\
0.67\end{array}$ & $\begin{array}{c}-0.0529 \\
-0.8\end{array}$ & 0.51 & $12.04^{* * *}$ & 70 \\
\hline $\begin{array}{l}\text { M } \\
\text { t-stat }\end{array}$ & $\begin{array}{c}0.9865 \\
21.43^{* * *}\end{array}$ & $\begin{array}{l}0.0121 \\
2.31^{* *}\end{array}$ & $\begin{array}{c}0.0253 \\
0.7\end{array}$ & $\begin{array}{c}-0.0046 \\
-1.76^{*}\end{array}$ & $\begin{array}{c}0.0877 \\
1.91^{\star}\end{array}$ & $\begin{array}{c}-0.0003 \\
-0.03\end{array}$ & $\begin{array}{c}-0.0002 \\
-0.99\end{array}$ & $\begin{array}{c}-0.0848 \\
-1.74^{*}\end{array}$ & 0.93 & $132.06^{* * *}$ & 73 \\
\hline $\begin{array}{l}\mathrm{PH} \\
\text { t-stat }\end{array}$ & $\begin{array}{l}0.5604 \\
4.14^{* * *}\end{array}$ & $\begin{array}{c}0.0102 \\
0.55\end{array}$ & $\begin{array}{c}-0.0800 \\
-1.1\end{array}$ & $\begin{array}{c}-0.0035 \\
-0.75\end{array}$ & $\begin{array}{c}-0.0331 \\
-0.39\end{array}$ & $\begin{array}{c}0.0277 \\
1.13\end{array}$ & $\begin{array}{c}-0.0002 \\
-0.36\end{array}$ & $\begin{array}{c}0.0031 \\
0.02\end{array}$ & 0.37 & $7.96^{\star * *}$ & 70 \\
\hline $\begin{array}{l}\mathrm{CO} \\
\text { t-stat }\end{array}$ & $\begin{array}{l}0.6826 \\
3.02^{* * *}\end{array}$ & $\begin{array}{c}0.0164 \\
0.71\end{array}$ & $\begin{array}{c}-0.1530 \\
-1.58\end{array}$ & $\begin{array}{c}0.0021 \\
0.3\end{array}$ & $\begin{array}{c}0.2229 \\
0.81\end{array}$ & $\begin{array}{c}0.0232 \\
0.52\end{array}$ & $\begin{array}{c}-0.0007 \\
-1.57\end{array}$ & $\begin{array}{c}-0.0401 \\
-0.2\end{array}$ & 0.46 & $2.59^{* *}$ & 62 \\
\hline $\begin{array}{l}\text { TR } \\
\text { t-stat }\end{array}$ & $\begin{array}{l}0.8871 \\
9.46^{* * *}\end{array}$ & $\begin{array}{c}-0.0019 \\
-0.26\end{array}$ & $\begin{array}{c}-0.0273 \\
-0.45\end{array}$ & $\begin{array}{c}0.0005 \\
0.62\end{array}$ & $\begin{array}{c}0.0109 \\
0.28\end{array}$ & $\begin{array}{c}-0.0023 \\
-0.2\end{array}$ & $\begin{array}{c}0.0002 \\
0.64\end{array}$ & $\begin{array}{c}0.0326 \\
0.64\end{array}$ & 0.90 & $113.72^{* * *}$ & 84 \\
\hline
\end{tabular}

\section{B: GMM-IV method}

\begin{tabular}{lcccccccc}
\hline Industry & FV_18 & SIZE & LEV & CAP & GRO & DEV & ESG & c \\
\hline BA & 0.4826 & 0.0129 & -0.2218 & 0.0021 & 0.1674 & -0.1426 & -0.0002 & -0.0105 \\
t-stat & $2.01^{* *}$ & 1.08 & $-2.03^{* *}$ & $2.53^{* *}$ & 0.91 & $-2.67^{* * *}$ & -0.34 & -0.08 \\
\hline CH & 0.6488 & 0.0159 & -0.0665 & -0.0013 & 0.0548 & 0.0201 & 0.0001 & -0.1062 \\
t-stat & $4.27^{* * *}$ & 1.24 & -1.38 & -0.46 & 0.4 & 0.93 & 0.1 & -0.9 \\
\hline F & 0.5069 & 0.0186 & -0.0638 & 0.0085 & 0.0884 & 0.0167 & -0.0018 & -0.0587 \\
t-stat & $1.84^{*}$ & 1.08 & -0.45 & $2.14^{* *}$ & 0.56 & 0.42 & -1 & -0.41 \\
\hline M & 0.9081 & 0.0134 & 0.0244 & -0.0032 & 0.0690 & 0.0028 & -0.0003 & -0.0939 \\
t-stat & $11.06^{* * *}$ & $1.82^{*}$ & 0.42 & -1.24 & 1.1 & 0.11 & -0.44 & -1.44 \\
\hline PH & 0.4363 & -0.0175 & -0.0520 & -0.0100 & -0.1283 & -0.0138 & 0.0022 & 0.2243 \\
t-stat & $1.94^{*}$ & -0.63 & -0.61 & -1.2 & -0.81 & -0.2 & 0.78 & 0.94 \\
\hline CO & 1.1419 & -0.0007 & -0.0320 & -0.0016 & 0.3739 & 0.0507 & -0.0016 & 0.0786 \\
t-stat & $3.7^{* * *}$ & -0.02 & -0.17 & -0.18 & $1.76^{*}$ & 0.87 & -1.35 & 0.29 \\
\hline TR & 0.9040 & 0.0108 & -0.0619 & 0.0015 & -0.0780 & -0.0116 & 0.0002 & -0.0795 \\
t-stat & $10.91^{* * *}$ & 0.65 & -0.75 & 0.93 & -0.73 & -0.64 & 0.39 & -0.57 \\
\hline
\end{tabular}

Comments: "DV_18" refers to the profitability of the previous year; " $c$ " is the constant. Regarding heteroscedasticity, the calculated standard errors are robust values. In the case of the GMM-IV method, the adjusted $\mathrm{R}^{2}$ (adj_R $\mathrm{R}^{2}$ ) can be a value under o or over 1 ; therefore the correctness of GMM-IV should be judged on the basis of the relevance test (filtering out weak instruments) and the exogeneity test. The results of the aforementioned tests confirm the applicability of the GMM-IV method. "DEV" is the short form for developing.

BA - Banking Sector; CH - Chemical Industry; F - Food Industry; M - Manufacture of Machinery; $\mathrm{PH}$ - Pharmaceutical Industry; CO - Commerce; TR - Transportation.

Significant variables at ${ }^{* *}-1.00 ;^{* *}-5.00$ and ${ }^{*}-10.00$ percent. 
Regarding the sign of the ESG variable, the results vary: in the case of three industries the value of the beta coefficient is positive, while, in the case of four industries, it is negative. Both methods revealed a positive relationship in transportation, while a negative relationship in the manufacture of machinery and commerce. As far as the other sectors are concerned, OLS and GMM-IV methods resulted in inverse sign. Another important result is that, excepting one industry, the value of coefficients does not significantly differ from zero. The only exception is the banking sector, where the difference is significant at $10.00 \%$ in the case of the OLS method. At the same time, the practical interpretability of the result is relatively little (in the event of upgrading from o to 100, the increase in the result was merely three basis points). On the whole, our first hypothesis is not supported by our calculations, i.e. at the usual significance levels, we cannot reject the usual null hypothesis, according to which the value of the ESG coefficient is o, i.e., in the short run, there is no significant relationship between return on sales and ESG performance. Basically, the received neutral relationship is consistent with the results of McWilliams - Siegel $(2000,2001)$ and the conclusions drawn by Ben Lahouel et al. (2019) in their analysis of airlines.

In the case of most control variables, we receive the expected sign; however, most of them cannot be considered to be significant, which is mainly due to short-term analysis and inclusion of the previous year's profitability (in accordance with the results by Garcia-Castro et al., 2010). Given the above, it can be stated that, in the short run, the profit of the previous year has the most significant impact on the performance of the current year.

The dependent variable in Table 3 is the ROC/WACC ratio, which expresses value creation better than ROS. Panels " $\mathrm{A}$ " and " $\mathrm{B}$ " of the table summarise the numerical output of regressions based on the OLS and GMM-IV methods, respectively. As in the case of return on sales, the overall picture related to ESG is heterogeneous, as well: when the OLS method was used, the coefficients of the banking sector, food industry and transportation were positive, while those of the chemical industry, manufacture of machinery, pharmaceutical industry and commerce were negative (namely, these signs corresponded to those experienced related to the ROS). The GMM method, which applied robust instrumental variables, resulted in a positive relation in four sectors (banking sector, chemical industry, commerce, transportation), while, in the case of the other three sectors, the relation was negative.

At the same time, based on the data of the table, in the short run, there seems to be no significant relationship between financial and ESG performance in either of the industries. On the whole, we can draw the same conclusion as in the case of our first hypothesis: nor is our second hypothesis supported by our calculations, i.e. at the usual significance levels, we cannot reject the usual null hypothesis, according to which the value of the ESG coefficient is o. 
Table 3

Relation between the value-added ratio (ROC/WACC) and ESG

\begin{tabular}{|c|c|c|c|c|c|c|c|c|c|c|c|}
\hline \multicolumn{12}{|c|}{ A: OLS method } \\
\hline Industry & FV_18 & SIZE & LEV & CAP & GRO & DEV & ESG & c & $\mathbf{a d j}_{2} \mathbf{R}^{2}$ & $\mathbf{F}$ & $\mathbf{N}$ \\
\hline \multirow{2}{*}{$\begin{array}{l}\text { BA } \\
\text { t-stat }\end{array}$} & 0.5184 & 0.0206 & 0.0359 & -0.0003 & 0.1668 & 0.0736 & 0.0003 & 0.2508 & 0.21 & $5.68^{\star * *}$ & 188 \\
\hline & $3.04^{* * *}$ & 1.12 & 0.16 & -0.47 & 0.59 & 1.37 & 0.36 & 0.8 & & & \\
\hline \multirow{2}{*}{$\begin{array}{l}\mathrm{CH} \\
\text { t-stat }\end{array}$} & 0.3086 & -0.2110 & 0.2024 & -0.0222 & 0.8262 & 0.3343 & -0.0041 & 2.5603 & 0.23 & $8.82^{\star * *}$ & 77 \\
\hline & 1.42 & $-2.29^{* *}$ & 0.42 & $-1.8^{*}$ & 0.78 & $2.25^{\star *}$ & -1.64 & $2.38^{* *}$ & & & \\
\hline \multirow{2}{*}{$F_{\text {t-stat }}$} & 1.1199 & -0.0401 & 0.5604 & -0.0351 & -1.1445 & -0.0685 & 0.0022 & 0.1639 & 0.61 & $14.8^{* * *}$ & 70 \\
\hline & $8.28^{* * *}$ & -0.33 & 0.72 & -1.22 & -0.86 & -0.44 & 0.7 & 0.16 & & & \\
\hline \multirow{2}{*}{$\mathrm{M}_{\mathrm{t} \text {-stat }}$} & 0.5081 & 0.1274 & 0.6466 & -0.0506 & -0.7591 & 0.0348 & -0.0017 & -0.5099 & 0.34 & $4.27^{\star * *}$ & 73 \\
\hline & $3.74^{* * *}$ & $2.1^{\star *}$ & 0.93 & $-2.1^{* *}$ & -1.14 & 0.23 & -0.51 & -0.81 & & & \\
\hline \multirow{2}{*}{$\begin{array}{l}\mathrm{PH} \\
\text { t-stat }\end{array}$} & 0.7013 & 0.2753 & -0.2258 & -0.0143 & -0.1138 & -0.0812 & -0.0014 & -1.7024 & 0.55 & $12.14^{* * *}$ & 70 \\
\hline & $5.33^{* * *}$ & $2.58^{* *}$ & -0.49 & -0.52 & -0.18 & -0.47 & -0.44 & $-2.07^{* *}$ & & & \\
\hline \multirow{2}{*}{$\begin{array}{l}\mathrm{CO} \\
\text { t-stat }\end{array}$} & 0.6773 & 0.068 & -0.2395 & 0.0139 & -2.9085 & 0.1698 & -0.0014 & -0.6034 & 0.64 & $21.66^{* * *}$ & 62 \\
\hline & $9.25^{* * *}$ & 0.91 & -0.47 & 0.6 & $-2.75^{* * *}$ & 0.87 & -0.58 & -0.8 & & & \\
\hline \multirow{2}{*}{$\begin{array}{l}\text { TR } \\
\text { t-stat }\end{array}$} & 0.6665 & 0.0237 & 0.624 & 0.0052 & -0.3122 & -0.0306 & 0.0019 & -0.1354 & 0.46 & $16.18^{* * *}$ & 84 \\
\hline & $7.09^{* * *}$ & 0.34 & $2.03^{\star *}$ & 0.63 & -0.65 & -0.27 & 0.91 & -0.21 & & & \\
\hline
\end{tabular}

B: GMM-IV method

\begin{tabular}{ccccccccc}
\hline Industry & FV_18 & SIZE & LEV & CAP & GRO & DEV & ESG & c \\
\hline BA & 0.5794 & 0.0584 & -0.1368 & 0.0045 & 0.4148 & -0.2465 & 0.0046 & -0.5361 \\
t-stat & $2.82^{* * *}$ & $1.71^{*}$ & -0.35 & $2.11^{* *}$ & 0.82 & $-1.67^{*}$ & 1.63 & -1.07 \\
\hline CH & 0.3393 & -0.1816 & -0.4934 & -0.0139 & 1.3218 & 0.2467 & 0.0019 & 2.2626 \\
t-stat & 1.33 & $-1.73^{*}$ & -0.79 & -0.83 & 1.03 & 1.3 & 0.37 & $1.88^{*}$ \\
\hline F & 1.0865 & 0.1085 & 0.2398 & -0.0057 & -0.5973 & 0.0083 & -0.0050 & -0.7841 \\
t-stat & $6.65^{* * *}$ & 0.76 & 0.26 & -0.15 & -0.42 & 0.03 & -0.48 & -0.62 \\
\hline M & 0.5377 & 0.123 & 1.3314 & -0.0408 & -1.3500 & 0.2263 & -0.0095 & -0.6347 \\
t-stat & $4.36^{* * *}$ & 1.62 & $1.74^{*}$ & -1.09 & -1.32 & 0.66 & -0.82 & -0.85 \\
\hline PH & 0.7807 & 0.1252 & 0.602 & -0.0479 & -0.5788 & 0.1817 & -0.0031 & -0.5330 \\
t-stat & $4.61^{* * *}$ & 0.74 & 0.96 & -1.27 & -0.65 & 0.39 & -0.19 & -0.44 \\
\hline CO & 0.6531 & 0.0415 & 0.5565 & 0.0189 & -2.6969 & 0.1749 & 0.0029 & -0.7729 \\
t-stat & $4.32^{* * *}$ & 0.41 & 1.03 & 0.62 & $-2.65^{* *}$ & 0.8 & 0.58 & -0.81 \\
\hline TR & 0.6858 & -0.0087 & 0.6153 & 0.0057 & -0.3894 & 0.0115 & 0.0001 & 0.1602 \\
t-stat & $6.7^{* * *}$ & -0.08 & 1.26 & 0.47 & -0.28 & 0.04 & 0.02 & 0.19 \\
\hline
\end{tabular}

Comments: "DV_18" refers to the profitability of the previous year; " $c$ " is the constant. Regarding heteroscedasticity, the calculated standard errors are robust values. In the case of the GMM-IV method, correctness should be judged on the basis of the relevance test (filtering out weak instruments) and the exogeneity test. The results of the aforementioned tests confirm the applicability of the GMM-IV method. "DEV" is the short form for developing.

BA - Banking Sector; CH - Chemical Industry; F - Food Industry; M - Manufacture of Machinery; PH - Pharmaceutical Industry; CO - Commerce; TR - Transportation.

Significant variables at ${ }^{* *}-1.00 ;{ }^{* *}-5.00$ and ${ }^{\star}-10.00$ percent. 
Our final conclusion is the following: in the short run, there seems to be no significant relation neither between accounting profitability and ESG, nor between the added value and ESG, which corresponds to the "neutrality" presented as the third hypothesis in the literature review. At the same time, based on our results, we believe that businesses can support the achievement of many of the sustainable development goals (SDGs) set by the UN, without sacrificing their profit in the short term. In light of the above, the internalisation of externalities may lead to additional costs. However, such costs are offset by benefits, i.e. companies can do "good" without "causing harm" to themselves.

\section{LIMITATIONS OF THE CALCULATIONS, FURTHER RESEARCH TRENDS}

Our findings are based on short-term examinations. It is worth conducting further research. By analysing panel data, general conclusions related to long-term impacts could be drawn. However, the compilation of panel databases requires circumspection, as information from several previous years has to be collected, which may result in the lack of data in many cases. To a certain extent, the use of the multiple imputation method might be the solution for handling the missing data.

The explanatory variables in our analysis were fundamentally based on accounting categories (however, the ROC/WACC ratio already partly reflects market values, as well), but even explicit market measures, such as Jensen's alpha or the Sharpe ratio should be calculated. Such performance measures are risk-adjusted capital market indicators. Concerning the measurement of different market anomalies and the performance of investment funds see studies by Back et al. (2013), Kovács et al. (2011) and Naffa (2009).

Our empirical analysis examined the overall ESG performance. Later, it could be practical to concentrate our research on the examination of the individual components, such as environmental, social and corporate governance factors separately. The so-called ESG disclosure scores should also be assessed. By doing this, it could be examined whether the companies which operate more transparently than their competitors perform better.

A closely related issue to the evaluation of ESG performance is that the methodology of each ESG rating firm is different, so different results may be obtained depending on which ESG rating firm's scores the researcher uses (see: Dorfleitner et al., 2015). We believe that a more comprehensive picture of the ESG-financial performance relationship would be obtained if the databases of several ESG rating firms could be analyzed. 
Finally, this analysis is suitable for comparison within industries, but there is a natural demand for the comparison of the ESG performance of companies irrespective of the industry. The methodological innovation of the ESG rating company Sustainalytics already fulfils this requirement (see: Stuart, 2020).

\section{SUMMARY}

In this study, we intended to find the answer to the research question on how the ESG performance of companies affects their short-term profitability and value creation. In our view, if the aforementioned relation is at least neutral, enterprises should focus on sustainability even in the short run, as, in this way, they can do good without sacrificing their profit-related goals. The importance of "Doing good" (or as the popular term in literature says "doing well while doing good") is a global issue nowadays, which the UN is trying to promote by setting sustainable development goals (SDGs). Our findings also help to decide whether external risks can be reduced by good ESG performance, maintaining the rational behaviour of companies (satisfying consumer needs by taking into account the profit motive) or, in other words, whether, in principle, the goals of the UN can be achieved.

To answer the research question, we conducted regression calculations. In addition to using the traditional, robust OLS (WLS) method, we applied an innovative GMM-IV method that uses distance instrumental variables. The use of the latter is justified by several well-known facts in literature, according to which the exogeneity assumption is often violated when the relation between financial performance and ESG performance is examined. Besides using the appropriate estimation method, our models were dynamic in the sense that, in accordance with recently published studies, the explanatory variables included the one-year lagged values of the dependent variables. In conclusion, the novelty of this study lies in the fact that, as far as we know, this version of the GMM-IV procedure has not been used by other researchers to assess ESG performance.

Our universe of analysis consists of companies traded in global capital markets; therefore, the benchmark was the MSCI ACWI Index. The dependent variables of regression calculation were the return on sales (ROS) ratio and the ROC/WACC ratio, which reflects added value more adequately; the ESG ratings, the S\&P Global SAM scores (earlier: RobecoSAM); control variables including profitability in the previous year (ROS, ROC/WACC), company size, capital intensity, leverage, the average growth of previous years as well as dummies measuring the company's membership to industries and developed/developing areas. The source of the data was Bloomberg, while the period of the analysis was 2019, , in line with the short-term focus of examination. The S\&P Global SAM ratings are not suit- 
able for comparison across industries, "only" for comparison within industries; therefore our analysis covered the following sectors: banking sector, chemical industry, food industry, manufacture of machinery, pharmaceutical industry, commerce and transportation.

The empirical findings of our study showed that in the short run, there seems to be no significant relationship neither between accounting profitability and ESG, nor between the added value and ESG. Our findings correspond to the "neutrality" presented as the third hypothesis in the literature; therefore they are in accordance with the conclusions in the studies by Ben Lahouel et al. (2019), Garcia-Castro et al. (2010), McWilliams and Siegel (2000, 2001). At first reading, the findings may sound negative for those who are committed to sustainable development and the ESG approach; however, based on our results, we believe that businesses can support the achievement of many of the sustainable development goals (SDGs) set by the UN. that the reason for this is that, in the short term, no extra profit derives from ESG-conscious behaviour, but it does not lead to a decrease in profit either. In the light of the above, although the internalisation of externalities may lead to additional costs, such costs are offset by the benefits, i.e. companies can do "good" for their stakeholders without "causing harm" to themselves.

\section{REFERENCES}

Aupperle, K. E. - Carroll, A. B. - Hatfield, J. D. (1985): An Empirical Examination of the Relationship between Corporate Social Responsibility and Profitability. The Academy of Management Journal 28(2), 446-463., https://doi.org/10.2307/256210.

BACK, K. - KApadia, N. - Ostdiek, B. (2013): Slopes as Factors: Characteristic Pure Plays (SSRN Scholarly Paper No. ID 2295993). Rochester, NY: Social Science Research Network, https://doi. org/10.2139/ssrn.2295993.

Bebchuк, L. A. - Cohen, A. - WANG, C. C. Y. (2013): Learning and the disappearing association between governance and returns. Journal of Financial Economics 108(2), 323-348., https://doi. org/10.1016/j.jfineco.2012.10.004

Ben Lahouel, B. - Gaies, B. - Ben Zaied, Y. - Jahmane, A. (2019): Accounting for endogeneity and the dynamics of corporate social - Corporate financial performance relationship. Journal of Cleaner Production, 230, 352-364., https://doi.org/10.1016/j.jclepro.2019.04.377.

Brammer, S. - PAvelin, S. (2006): Voluntary Environmental Disclosures by Large UK Companies. Journal of Business Finance \& Accounting, 33(7-8), 1168-1188., https://doi.org/10.1111/j.14685957.2006.00598.x.

Brammer, S. - PAvelin, S. (2008): Factors influencing the quality of corporate environmental disclosure. Business Strategy and the Environment 17(2), 120-136., https://doi.org/10.1002/bse.506.

Capon, N. - Farley, J. U. - Hoenig, S. (1990): Determinants of Financial Performance: A MetaAnalysis. Management Science 36(10), 1143-1159., https://doi.org/10.1287/mnsc.36.10.1143.

Clarkson, M. B. E. (1995): A Stakeholder Framework for Analyzing and Evaluating Corporate Social Performance. The Academy of Management Review 20(1), 92-117., https://doi.org/10.2307/258888. 
Cormier, D. - Ledoux, M. - Magnan, M. (2011): The informational contribution of social and environmental disclosures for investors. Management Decision 49(8), 1276-1304., https://doi. org/10.1108/00251741111163124

Cormier, D. - Magnan, M. (2003): Environmental reporting management: a continental European perspective. Journal of Accounting and Public Policy 22(1), 43-62., https://doi.org/10.1016/So2784254(02)00085-6.

Dagenais, M. G. - Dagenais, D. L. (1997): Higher moment estimators for linear regression models with errors in the variables. Journal of Econometrics 76(1), 193-221., https://doi.org/10.1016/03044076(95)01789-5.

DAM, L. (2008): Corporate social responsibility and financial markets (dissertation). Groningen (Netherlands): University of Groningen.

DAUGAARD, D. (2019): Emerging new themes in environmental, social and governance investing: a systematic literature review. Accounting \& Finance, acfi.12479., https://doi.org/10.1111/acfi.12479.

Dorfleitner, G. - Halbritter, G. - Nguyen, M. (2015): Measuring the level and risk of corporate responsibility - An empirical comparison of different ESG rating approaches. Journal of Asset Management 16(7), 450-466., https://doi.org/10.1057/jam.2015.31.

Durbin, J. (1954): Errors in Variables. Revue de l'Institut International de Statistique / Review of the International Statistical Institute 22(1/3), 23-32., https://doi.org/10.2307/1401917.

Escrig-Olmedo, E. - Fernández-Izquierdo, M. Á. - Ferrero-Ferrero, i. - Rivera-Lirio, J. M. - MuÑoz-Torres, M. J. (2019): Rating the Raters: Evaluating how ESG Rating Agencies Integrate Sustainability Principles. Sustainability 11(3), 915., https://doi.org/10.339o/su11030915.

Freeman, R. E. (2010): Strategic Management: A Stakeholder Approach. New York, NY: Cambridge University Press.

Friedman, M. (1970, September 13): The Social Responsibility of Business Is to Increase Its Profits. The New York Times Magazine. Retrieved from http://link.springer.com/10.1007/978-3-54070818-6_14.

Garcia-Castro, R. - Ariño, M. A. - Canela, M. A. (2010): Does Social Performance Really Lead to Financial Performance? Accounting for Endogeneity. Journal of Business Ethics 92(1), 107126., https://doi.org/10.1007/s10551-009-0143-8.

GSIA (2018): Global Sustainable Investment Review 2018. GSIA. Retrieved from http://www.gsi-alliance.org/trends-report-2018/.

Günther, E. - Hoppe, H. - Endrikat, J. (2012): Corporate financial performance and corporate environmental performance: a perfect match? Zeitschrift Für Umweltpolitik Und Umweltrecht $34,279-296$.

Hamilton, S. - Jo, H. - Statman, M. (1993): Doing Well While Doing Good? The Investment Performance of Socially Responsible Mutual Funds. Financial Analysts Journal 49(6), 62-66., https://doi.org/10.2469/faj.v49.n6.62.

Hillman, A. J. - Keim, G. D. (2001): Shareholder value, stakeholder management, and social issues: what's the bottom line? Strategic Management Journal 22(2), 125139., https://doi.org/10.1002/10970266(200101)22:2<125::AID-SMJ150>3.0.CO;2-H.

Ielasi, F. - Rossolini, M. (2019): Responsible or Thematic? The True Nature of SustainabilityThemed Mutual Funds. Sustainability 11(12), 3304., https://doi.org/10.339o/su11123304.

Johnson, S. A. - Moorman, T. C. - Sorescu, S. (2009): A Reexamination of Corporate Governance and Equity Prices. Review of Financial Studies 22(11), 4753-4786., https://doi.org/10.1093/ rfs/hhpo18.

J.P. Morgan (2019): J.P. Morgan perspective - ESG Investing 2019: Climate Change Everything. New York, NY.

JuHÁsz, PÉTER (2018): Vállalatértékelési számitások: Feladatok és megoldások [Company Assessment Calculations: Tasks and Solutions], 1st ed. Budapest: Budapesti Corvinus Egyetem. 
Kerti, Noémi Alíz - Keresztúri, Judit Lilla (2017): Az osztalékpolitika ágazati hatásának érvényesülése Magyarországon [The Sectorial Impact of Dividend Policy in Hungary]. Köz-Gazdaság 12(3), 75-91.

KovÁcs, Erzsébet (2014): Többváltozós adatelemzés [Multivariate data analysis]. Budapest: Typotex.

Kovács, Erzsébet - Dömötör, BARbara - NAFFA, Helena (2011): Investment Decisions in Crises - A Study of Private Pension Fund Investments. Acta Oeconomica 61(4), 389-412.

KPMG (2020): KPMG 2020 CEO Outlook: COVID-19 Special Edition (No. 137116-G), 1-23. KPMG. Retrieved from https://home.kpmg/content/dam/kpmg/xx/pdf/2020/o9/kpmg-2020-ceo-outlook.pdf.

LI, X. - LI, C. - WANG, Z. - JiAO, W. - PANG, Y. (2020): The effect of corporate philanthropy on corporate performance of Chinese family firms: The moderating role of religious atmosphere. Emerging Markets Review 100757, https://doi.org/10.1016/j.ememar.2020.100757.

Liu, W. - Shao, X. - De Sisto, M. - Li, W. H. (2020): A new approach for addressing endogeneity issues in the relationship between corporate social responsibility and corporate financial performance. Finance Research Letters 101623., https://doi.org/10.1016/j.frl.2020.101623.

Makni, R. - Francoeur, C. - Bellavance, F. (2009): Causality Between Corporate Social Performance and Financial Performance: Evidence from Canadian Firms. Journal of Business Ethics 89(3), 409-422., https://doi.org/10.1007/s10551-008-0007-7.

Martí-Ballester, C.-P. (2020): Financial Performance of SDG Mutual Funds Focused on Biotechnology and Healthcare Sectors. Sustainability 12(5), 2032., https://doi.org/10.3390/su12052032.

McWilliams, A. - Siegel, D. (2000): Corporate social responsibility and financial performance: correlation or misspecification? Strategic Management Journal 21(5), 603-609., https://doi. org/10.1002/(SICI)1097-0266(200005)21:5<603::AID-SMJ101>3.0.CO;2-3.

McWilliams, A. - Siegel, D. (2001): Corporate social responsibility: A theory of the firm perspective. Academy of Management Review 26(1), 117-127., https://doi.org/10.2307/259398.

Menz, K.-M. (2010): Corporate Social Responsibility: Is it Rewarded by the Corporate Bond Market? A Critical Note. Journal of Business Ethics 96(1), 117-134., https://doi.org/10.1007/s10551-0100452-y.

Mitchell, R. K. - Agle, B. R. - Wood, D. J. (1997): Toward a Theory of Stakeholder Identification and Salience: Defining the Principle of Who and What Really Counts. The Academy of Management Review 22(4), 853-886., https://doi.org/10.2307/259247.

Moskowitz, M. (1972): Choosing socially responsible stocks. Business and Society Review 1(1), 71-75.

NAfFa Helena (2009): Eszközárazási anomáliák többváltozós modellje [The Multivariable Model of Asset Pricing Anomalies]. Hitelintézeti Szemle 8(6), 516-527.

Naffa Helena (2018): Bloomberg a felsőoktatásban [Bloomberg in Higher Education]. Számvitel Adó Könyvvizsgálat: SZAKMA, 60(4), 45.

Oiкonomou, I. - Brooks, C. - Pavelin, S. (2012): The Impact of Corporate Social Performance on Financial Risk and Utility: A Longitudinal Analysis. Financial Management 41(2), 483-515., https://doi.org/10.1111/j.1755-053X.2012.01190.x.

Orlitzky, M. - Schmidt, F. L. - Rynes, S. L. (2003): Corporate Social and Financial Performance: A Meta-Analysis. Organization Studies 24(3), 403-441., https://doi.org/10.1177/01708406030240 03910 .

PAL, M. (1980): Consistent moment estimators of regression coefficients in the presence of errors in variables. Journal of Econometrics 14(3), 349-364., https://doi.org/10.1016/0304-4076(80)90032-9.

Patten, D. M. (1991): Exposure, legitimacy, and social disclosure. Journal of Accounting and Public Policy 10(4), 297-308., https://doi.org/10.1016/0278-4254(91)90003-3.

Porter, M. E. - van der Linde, C. (1995): Toward a New Conception of the Environment-Competitiveness Relationship. Journal of Economic Perspectives 9(4), 97-118., https://doi.org/10.1257/ jep.9.4.97. 
Preston, L. E. - O'BAnnon, D. (1997): The corporate social-financial performance relationship: A typology and analysis. Business \& Society 36(4), 419-429., https://doi. org/10.1177/000765039703600406.

QiU, Y. - Shaukat, A. - Tharyan, R. (2016): Environmental and social disclosures: Link with corporate financial performance. The British Accounting Review 48(1), 102-116., https://doi. org/10.1016/j.bar.2014.10.007.

RACICOT, F.-É. (2015): Engineering robust instruments for GMM estimation of panel data regression models with errors in variables: a note. Applied Economics 47(10), 981-989., https://doi.org/10.10 80/00036846.2014.985373.

Racicot, F.-É. - Rentz, W. F. (2015): The Pástor-Stambaugh empirical model revisited: Evidence from robust instruments. Journal of Asset Management 16(5), 329-341., https://doi.org/10.1057/ jam.2015.22.

Racicot, F.-É. - Rentz, W. F. - Tessier, D. - Théoret, R. (2019): The conditional Fama-French model and endogenous illiquidity: A robust instrumental variables test. PLOS ONE 14(9), e0221599., https://doi.org/10.1371/journal.pone.0221599.

RACiCot, F.-É. - ThÉoret, R. (2014): Cumulant instrument estimators for hedge fund return models with errors in variables. Applied Economics 46(10), 1134-1149., https://doi.org/10.1080/00036846 .2013 .868591 .

Roy, R. - Shijin, S. (2018): A six-factor asset pricing model. Borsa Istanbul Review 18(3), 205-217., https://doi.org/10.1016/j.bir.2018.02.001.

Russo, M. V. - Fouts, A. (1997): A Resource-Based Perspective on Corporate Environmental Performance and Profitability. Academy of Management Journal 40(3), 534-559., https://doi. org/10.5465/257052.

STUART, E. (2020): Morningstar Sustainability Ratings: The Impact. Retrieved October 31 2020, from https://www.morningstarfunds.ie/ie/news/201389/morningstar-sustainability-ratings-the-impact.aspx.

Szabó, Ágnes - Juhász, PÉTer (2019a): A munkahelyi egészségprogramok értékteremtésének mérési lehetőségei [Workplace Health Programmes as Risk Management Tools]. Vezetéstudomány 50(2), 59-71.

SzABó, Ágnes - Juhász, PÉTer (2019b): Workplace Health Programmes as Risk Management Tools [A munkahelyi egészségprogramok mint kockázatkezelési eszközök]. Economy and Finance 6(2), 165-188., https://doi.org/10.33908/EF.2019.2.2

Ullmann, A. A. (1985): Data in Search of a Theory: A Critical Examination of the Relationships among Social Performance, Social Disclosure and Economic Performance of U. S. Firms. The Academy of Management Review 10(3), 540-557., https://doi.org/10.2307/258135

United Nations (2015): Transforming our world: the 2030 Agenda for Sustainable Development. Retrieved from https://sustainabledevelopment.un.org/post2015/transformingourworld.

VANCE, S. C. (1975): Are socially responsible corporations good investment risks? Management Review 64(8), 19-24.

Waddock, S. A. - Graves, S. B. (1998): The Corporate Social Performance-Financial Performance Link. Strategic Management Journal 18(4), 303-319., https://doi.org/10.1002/(SICI)10970266(199704)18:4<303::AID-SMJ869>3.0.CO;2-G.

WAGNER, M. (2005): How to reconcile environmental and economic performance to improve corporate sustainability: corporate environmental strategies in the European paper industry. Journal of Environmental Management 76(2), 105-118., https://doi.org/10.1016/j.jenvman.2004.11.021.

Wintoki, M. B. - Linck, J. S. - NetTer, J. M. (2012): Endogeneity and the dynamics of internal corporate governance. Journal of Financial Economics 105(3), 581-606., https://doi.org/10.1016/j. jfineco.2012.03.005. 